\title{
Short communication \\ Persistence and proliferation of some unicellular algae in drinking water systems as result of their heterotrophic metabolism
}

\author{
Francesc Codony , Anna M Miranda and Jordi Mas \\ Department of Genetics and Microbiology, Autonomous University of Barcelona, E-08193 Bellaterra, Spain
}

\begin{abstract}
Drinking water systems have a complex structure and are characterised by the absence of light, the presence of disinfectants and by low levels of nutrients. Several kinds of bacteria, protozoa, algae and fungi can be found in tap water. Little is known about the ecology of algae in drinking water systems, although their capacity to produce toxins and modify taste and odour has been described. In order to assess the presence and persistence of unicellular algae as well as their ability for heterotrophic growth as a mechanism for survival in water distribution networks, we carried out a one year study of the drinking water from the Bellaterra campus of the Autonomous University of Barcelona. Unicellular algae were isolated by membrane filtration on plates of synthetic medium containing organic matter as an energy source (R2A).

Oocystis sp. (unicellular green algae) and Xenococcus sp. (cyanobacteria) were routinely isolated and cultured using the procedure mentioned above. The results demonstrate the ability of some microalgae to grow in the dark as a consequence of their heterotrophic metabolism and illustrate the probable survival mechanism of some algal species species in these systems, which can be related to the possibility of algae regrowth in drinking water systems.
\end{abstract}

\section{Introduction}

Drinking water is a particular ecosystem with special characteristics such as the absence of light, the presence of disinfectants and the existence of low nutrient levels. From origin to destination, through kilometres of pipes with different diameters and materials, water flows through different pumping stations, deposits and booster chlorination points.

Water supply released into the distribution system evolves during its passage throughout the system as consequence, to as large extent, of microbial activity. These quality changes most often cause taste, odour and colour complaints. In other cases, as result of bacterial regrowth, the sanitary quality of water decreases, therefore resulting in non-compliance with national regulations.

Most components in water distribution networks may become excellent microbial environments. However, the persistence and proliferation of microorganisms in these systems is influenced by a number of factors (Geldreich, 1996).Most exposed surfaces are colonised by microorganisms, forming biofilms (Ridgway and Olson, 1981).The characteristics of these biofilms vary widely, from sparsely colonised surfaces, to thick complex layers with a depth of several micrometers formed by a densely interwoven structure of extracellular polymers and microbial cells (Lechevallier et al., 1987; Stewart et al., 1993). Microbial growth within the biofilm and release of the offspring into the overlaying water contributes to increased microbial counts in the water phase. On the other hand, the structure of the biofilms contributes to shelter occasional contaminants from the effects of chlorine, thus prevent-

* To whom all correspondence should be addressed.

New address: Laboratori de Salut Pública de Barcelona, Avinguda Drassanes 13-15, e-08001 Barcelona Spain

ㄲㅛㅛ 349344394 05; fax 349344306 11; e-mail: fcodony@dtb.scs.es Received 20 February 2002; accepted in revised form 6 November 2002. ing adequate disinfection and potentially allowing regrowth of contaminants in the water distribution network (Lechevallier et al.,1988; Camper, 1994). Evidence is available that shows the development of biofilms containing algae (Allen et al., 1980).

Microbiological quality of drinking water is systematically controlled by water suppliers using the levels of microbial indicators such as total and faecal coliforms, or heterotrophic plate counts (HPC) as reference. The microbial indicators routinely used, are good tools for the sanitary control of water but they only offer a partial view of the microbial dynamics. Therefore, the vision obtained with standard microbial analysis is not enough to understand the full complexity and diversity of drinking water systems. In tap water we can find several kinds of bacteria, protozoa, algae and fungi.

Algae can affect water characteristics in two ways. First, as occurs with actinomycetes, algae can alter organoleptic properties (Nyström et al., 1992; Jensen et al., 1994; Bower et al., 1988). Second, certain cyanobacteria can produce toxins with pernicious health effects (Codd, 1995; Sivonen, 1996). Cyanobacteria and their toxins can cause diarrhea as an acute effect and cancer in the ultimate instance (Rose et al., 1999).

The inclusion of cyanobacteria, freshwater algae and their toxins in the drinking water contaminant candidate list (CCL) U S Environmental Protection Agency (EPA) in 1998, illustrates the increasing interest in such micro organisms and their possible impact on public health.

The CCL is a list of contaminants which, at the time of publication, are not subject to any proposed or promulgated national primary drinking water regulation, but which are known or expected to occur in public water systems, and may require regulations. CCL will be the primary list of priority contaminants for the agency's drinking water program (U S EPA, 1998a; b). For this microbial group the research of analytical methods has been pointed as one of the priorities. 


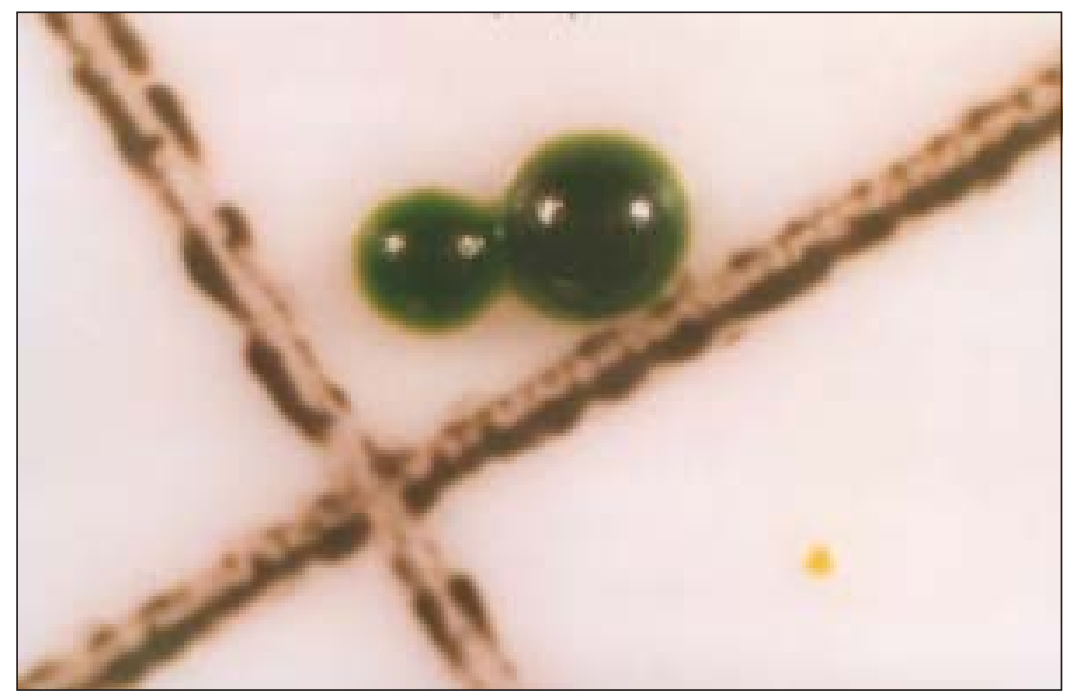

Photo 1

Colonial morphology of Oocystaceae. Incubation under light, $22^{\circ} \mathrm{C}, 18 \mathrm{~d}$

There is little information on algae in drinking water. Currently, morphological studies and cultures with classical culture media can be used to study these phototropic micro-organisms. For example, the Standard Methods for the Examination of Water and Wastewater (Clesceri et al. 1998) provide the diagnostic keys for the identification of drinking-water algae. Most of these micro organism are totally dependent on light as a source of energy for growth, and for this reason their presence on drinking water systems is accepted as an anecdotic fact and may be attributed to treatment limitations.

Although uptake ant utilisation of organic carbon have been well established for a wide variety of algae in laboratory culture studies such processes have been considered inconsequential for algae under natural conditions (Nielson et al., 1974). Nevertheless this general rule has exceptions. For example Parker (1961) demonstrated growth of Bracteaccoccus in soil even in darkness.

In this work, a procedure based on membrane filtration method and a culture media with organic matter was used in order to isolate heterotrophic algae from tap water during one year. The results shows the ability of isolated strains to grow in darkness, using organic matter as a source of carbon. This result suggest that the presence of few microscopic algae in drinking water systems could be attributed to their growth through the system, probably into the biofilms.

\section{Experimental}

Drinking water from the microbial physiology laboratory in the Department of Genetics and Microbiology at the Bellaterrra campus of he Autonomous University of Barcelona, was studied during one year.

\section{Algae definition}

Unicellular micro-organism with photosynthetic pigments and morphologically compatible with diagnostic keys. The phototropic growth capacity in a mineral culture media (BG-11, Sigma) and presence of chlorophyll $a$ (determined from "in vivo" spectra) were tested in several isolates of each algal type.

\section{Algae identification}

Micro algae wer characterised by microscopic observation using diagnostic keys from Standard Methods (Clesceri et al., 1998) as well as the Bergey's Manual of Systematic Bacteriology (Staley et al., 1989). Additionally, the Süsswasseflora von Mitteleuropa (Ettl et al., 1988) was used as a reference manual.

\section{Sampling}

Once a week, after allowing tap water to run for $2 \mathrm{~min}$, samples were collected in $1 \mathrm{I}$ sterile Pyrex bottles with sodium thiosulphate ( $1 \mathrm{ml}$ of $5 \%$ solution). Samples were kept in the dark at $4{ }^{\circ} \mathrm{C}$ and were processed within the next $2 \mathrm{~h}$.

\section{Isolation of heterotrophic algae}

Plate counts of microalgae were routinely performed by membrane filtration (MF) using cellulose nitrate (Millipore) filters with a pore size of $0.45 \mu \mathrm{m}$. Filters were incubated in R2A agar plates for $21 \mathrm{~d}$ at $22^{\circ} \mathrm{C}$ under light (fluorescent lamps) or in the dark. R2A was supplemented with gentamicine sulfate $\left(80 \mathrm{mg} \cdot \mathrm{l}^{-1}\right)$ in order to minimise heterotrophic bacterial growth, and allow the concentration of larger sample volumes to increase detection level. Agar plates were sealed with parafilm, in order to prevent agar dehydration. All the culture conditions and medium supplementation were tested previously in our laboratory.

The plates were checked once a week. After 3 weeks each colony morphology was enumerated and some were microscopically examined.

\section{Statistical analysis}

The significance of the difference between means was calculated using the Mann-Whitney U test (giving a P value and $95 \%$ confidence intervals for the difference in mean rank). Statistical tests were conducted using SPSS statistical software for windows operating system (Version 9.0, SPSS, Chicago).

\section{Results}

Most samples (97\%) were positive for algal growth although only two morphologies were detected. Morphology Type 1 (Photo 1) was green, circular and with regular perimeter. These colonies were formed by eucariotic algae that belong to the order of Chlorococcales, the Oocystaceae group and were identified as Oocystis sp. Morphology Type 2 (Photo 2) had an irregular perimeter and their color changed from yellow in younger colonies, 
Photo 2

Colonial morphology of Xenococcus $s p$. Incubation under light, $22^{\circ} \mathrm{C}, 18 \mathrm{~d}$. Two colonies with different pigmentation. The right colony shows the typical yellow colour before acquiring green pigmentation (left colony).

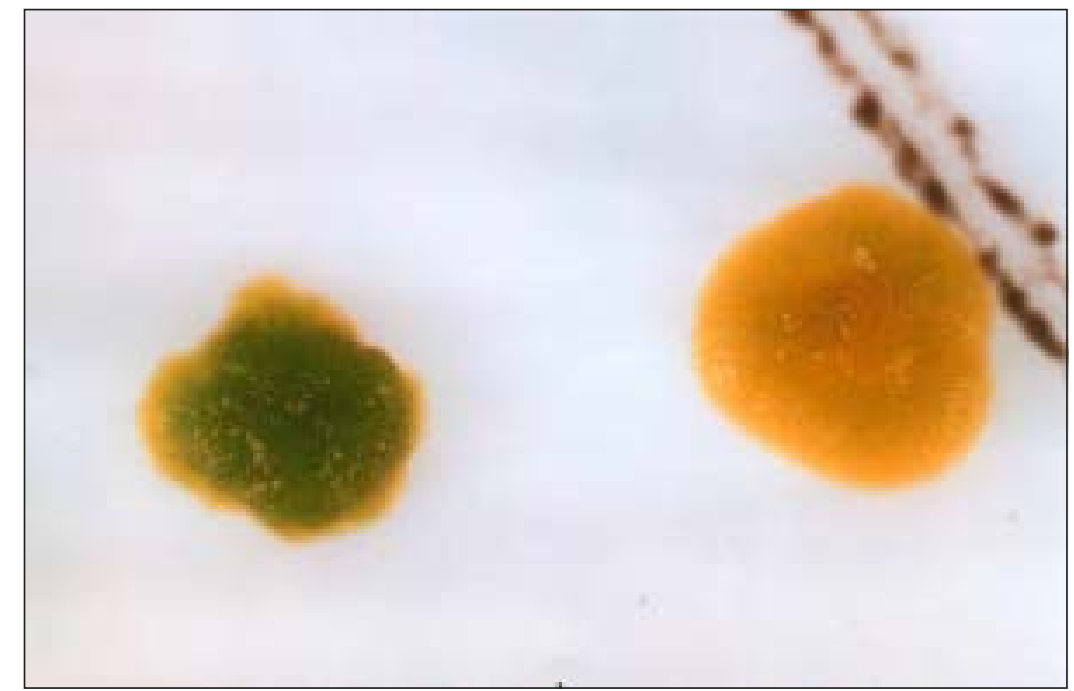

to green in older colonies. These colonies were formed by cyanobacteria belonging to the Pleurocapsales group and were identified as Xenococcus sp.

Cyanobacterial numbers were superior to chlorococcal group in both cases (see Table 1) (light $\mathrm{p}=0.006$, darkness $\mathrm{p}<0.001$ ). Although algae numbers can oscillate in different samples, no differences were observed between seasons.

Three weeks is an optimum time to clearly detect algal growth. Plates incubated in the light showed colonies after only two weeks, but plates incubated in the dark needed at least three weeks. When plates were incubated in darkness in some cases the invasive growth of fungi colonies was observed which did not allow the quantification of algae. For this reason the number of plates analysed under these conditions (shown in Table 1) is lower than the number of plates incubated in the light.

The numbers of algae detected were very low. In most cases values were lower than $100 \mathrm{cfu} \cdot \mathrm{l}^{-1}$. After three weeks, the counts of plates incubated in the light were higher than those of plates incubated in darkness $(\mathrm{p}=0.005)$.

\section{Discussion}

Two different hypotheses on the origin of algae in drinking water can be considered. First, it can be assumed that water treatments are not $100 \%$ effective (Steynberg et al., 1998; 1996) in removing algae. For this reason some of them are capable of penetrating in the drinking water systems. Since algae can travel all the way from origin to the end point, the levels detected in tap water are exclusively from algae not removed by treatment.

Secondly, some of these algae could proliferate or survive in the system in the dark, using the ability of some genera to develop heterothophic metabolisms. The ability of some microscopic algae to show mixotrophic and/or heterotrophic metabolism has been reported previously (extensively reviewed by Neilson and Lewis,1974). These microscopic algae, having a relatively active role, could become members of the normal flora of drinking water systems. In most pipe surfaces, the development of biofilms containing algae and bacteria has been proven (Allen et al., 1980). In this case, it is logical to consider the possibility of algae regrowth, probably into the biofilms.

Two facts can support this hypothesis. First, the algae detected have the ability to grow in the dark using organic matter as a source of carbon. Second, the detected levels do not show a clear seasonal variability therefore indicating that the presence of algae is not

\begin{tabular}{|c|c|c|c|c|}
\hline \multicolumn{5}{|c|}{$\begin{array}{c}\text { TABLE } 1 \\
\text { Algae levels, cfu }\left.\cdot\right|^{-1}, 21 \mathrm{~d} \text { at } 22^{\circ} \mathrm{C}\end{array}$} \\
\hline & \multicolumn{2}{|c|}{ Light } & \multicolumn{2}{|c|}{ Dark } \\
\hline & $\begin{array}{l}\text { Oocystis } \\
\text { sp. }\end{array}$ & $\begin{array}{l}\text { Xenococcus } \\
\text { sp. }\end{array}$ & $\begin{array}{l}\text { Oocystis } \\
\text { sp. }\end{array}$ & $\begin{array}{l}\text { Xenococcus } \\
\text { sp. }\end{array}$ \\
\hline mean & 61 & 96 & 12 & 73 \\
\hline SD. & 104 & 114 & 50 & 110 \\
\hline $\max$ & 560 & 540 & 270 & 476 \\
\hline min. & 0 & 0 & 0 & 0 \\
\hline $\mathrm{n}$ & 58 & 58 & 32 & 32 \\
\hline
\end{tabular}

affected by the seasonal changes occurring in the surace waters used for supply.

\section{Acknowledgments}

Dr. S. Sabater, from the University of Barcelona for the first identification of isolated strains. Societat General d'Aigües de Barcelona and Dr. F. Ribas for sponsoring this study. The work was supported by grants BOS2000-0139 REN2000-0332-P4 from the Spanish Ministery for Science and Technology to Jordi Mas.

\section{References}

ALLEN MJ, TAYLOR RH and GELDREICH EE (1980) The occurrence of microorganisms in water main incrustations. J. AWWA 72 614-625.

BOWER EJ and CROWEPB (1988) Biological processes in drinking water treatment. J. AWWA 72 514-625.

CAMPER AK (1994) Coliform regrowth and biofilm accumulation in drinking water systems: A review. In: Geesey GG, Lewandowski Z and Flemming HC (ed.) Biofouling and Biocorrosion in Industrial Water Systems. CRC Press, Boca Raton. 91-105.

CODD GA (1995) Cyanobacterial toxins: Occurrence, properties and biological significance. Water Sci. Technol. 32 149-156.

ETTLH and GAERTNER G(ed.) (1988) Süsswasserflora von Mitteleuropa. Gustav Fischer Verlag, Stuttgart.

GELDREICH EE (1996) Microbial Quality of Water in Distribution Systems. CRC Press, Boca Raton.

JENSEN SE, ANDERS CL, GOATCHER LJ, PERLEY T, KENEFICK S and HRUDEY SE (1994) Actinomycetes as a factor in odor oroblems affecting drinking water from the North Saskatchewan River. Water Res. 6 1393-1401. 
LECHEVALLIER MW, BABCOCK TM and LEE RG (1987) Examination and characterization of distribution system biofilms. Appl. Environ. Microbiol. 53 2714-2724.

LECHEVALLIER MW, CAWTHON CD and LEE RG (1988) Factors promoting survival of bacteria in chlorinated water supplies. Appl. Environ. Microbiol. 54 649-654.

NEILSON AH and LEWIN R A (1974) The uptake and utilization of organic carbon by algae: an essay in comparative biochemistry. Phycol. 3 227-264

NYSTRÖM A, GRIMVALL A, KRANTZ-RÜLCKER C., SÄVENHED R and AKERSTRAND K (1992) Drinking Water Off-Flavor caused by 2,4,6-trichloroanisole. Water Sci. Techol. 2 241-249.

PARKER BC (1961) Facultative heterotrophy in certain soil algae from the ecological point of view. Ecol. 42 381-386.

RIDGWAY HF and OLSON BF (1981) Scanning electron microscope evidence for bacterial colonization of a drinking-water distribution system. Appl. Environ. Microbiol. 41 274-287.

ROSEJB, ATLAS RM, GERBA CP, GILCHRIST MJR, LECHEVALLIER MW, SOBSEY MD, YATES MV, CASSELL GH and TEIDJE JM (1999) Microbial Pollutants in Our Nation's Water. Environmental and Public Health Issues. American Society for Microbiology. http://wwww.asmusa.org/pasrc/reports.htm

SIVONEN K (1996) Cyanobacterial toxins and toxins production. Phycol. 35 (6) $12-24$.
STALEY JT, BRYANT MP and HOLT JG (1989) Oxygenic photosynthetic bacteria. In: Hensyl WR (ed.) Bergey's Manual of Systematic Bacteriology Vol 3, Williams \& Wilkins Co., Baltimore Md. 1711-1746.

STANDARD METHODS (1998) Standard Methods for the Examination of Water and Waste Water (20th edn.) Clesceri S, Greenberg AE and Eaton AD (ed.) American Public Health Association, Washington, DC.

STEWART PS, PEYTON BM, DRURY WJ and MURGA R (1993) Quantitative observations of heterogeneities in Pseudomonas aeruginosa biofilms. Appl. Environ. Microbiol. 59 327-329.

STEYNBERG MC, ADAM K and PIETERSE AJH (1998) An algal monitoring protocol: The strategic link between reservoir and treatment process. Water Sci. Technol. 37 153-159.

STEYNBERG MC, PIETERSE AJ and GELDENHUYS JC (1996) Improved coagulation and filtration of algae as a result of morphological and behavioral changes due to pre-oxidation. J. Water SRT-Aqua 6 292-298.

US ENVIRONMENTAL PROTECTION AGENCY (1998a) Announcement of the Drinking Water Contaminant Candidate List. Federal Register. 63. n40: 10273-87

US ENVIRONMENTAL PROTECTION AGENCY (1998b) Office of Ground Water and Drinking Water Drinking Water Contaminant Candidate List. EPA 815-F-98-002. 